\title{
Front Matter: Volume 10577
}

, "Front Matter: Volume 10577," Proc. SPIE 10577, Medical Imaging 2018: Image Perception, Observer Performance, and Technology Assessment, 1057701 (14 May 2018); doi: 10.1117/12.2323943

SPIE. Event: SPIE Medical Imaging, 2018, Houston, Texas, United States 


\title{
PROGRESS IN BIOMEDICAL OPTICS AND IMAGING
}

\section{Image Perception, Observer Performance, and Technology Assessment}

\author{
Robert M. Nishikawa \\ Frank W. Samuelson
}

11-12 February 2018

Houston, Texas, United States

Sponsored by

SPIE

Co-sponsored by

DECTRIS Ltd. (Switzerland)

Cooperating Organizations

AAPM-American Association of Physicists in Medicine (United States)

IFCARS - International Foundation for Computer Assisted Radiology and Surgery (Germany)

MIPS-Medical Image Perception Society (United States)

RSNA-Radiological Society of North America (United States)

WMIS-World Molecular Imaging Society

Published by

SPIE

Volume 10577 
The papers in this volume were part of the technical conference cited on the cover and title page. Papers were selected and subject to review by the editors and conference program committee. Some conference presentations may not be available for publication. Additional papers and presentation recordings may be available online in the SPIE Digital Library at SPIEDigitalLibrary.org.

The papers reflect the work and thoughts of the authors and are published herein as submitted. The publisher is not responsible for the validity of the information or for any outcomes resulting from reliance thereon.

Please use the following format to cite material from these proceedings:

Author(s), "Title of Paper," in Medical Imaging 2018: Image Perception, Observer Performance, and Technology Assessment, edited by Robert M. Nishikawa, Frank W. Samuelson, Proceedings of SPIE Vol. 10577 (SPIE, Bellingham, WA, 2018) Seven-digit Article CID Number.

ISSN: 1605-7422

ISSN: 2410-9045 (electronic)

ISBN: 9781510616431

ISBN: 9781510616448 (electronic)

Published by

SPIE

P.O. Box 10, Bellingham, Washington 98227-0010 USA

Telephone +1 3606763290 (Pacific Time) · Fax +1 3606471445

SPIE.org

Copyright (c) 2018, Society of Photo-Optical Instrumentation Engineers.

Copying of material in this book for internal or personal use, or for the internal or personal use of specific clients, beyond the fair use provisions granted by the U.S. Copyright Law is authorized by SPIE subject to payment of copying fees. The Transactional Reporting Service base fee for this volume is $\$ 18.00$ per article (or portion thereof), which should be paid directly to the Copyright Clearance Center (CCC), 222 Rosewood Drive, Danvers, MA 01923. Payment may also be made electronically through CCC Online at copyright.com. Other copying for republication, resale, advertising or promotion, or any form of systematic or multiple reproduction of any material in this book is prohibited except with permission in writing from the publisher. The CCC fee code is 1605$7422 / 18 / \$ 18.00$.

Printed in the United States of America.

Publication of record for individual papers is online in the SPIE Digital Library.

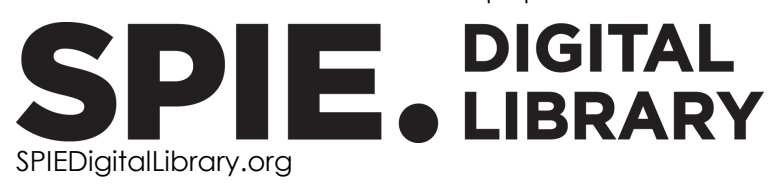

Paper Numbering: Proceedings of SPIE follow an e-First publication model. A unique citation identifier (CID) number is assigned to each article at the time of publication. Utilization of CIDs allows articles to be fully citable as soon as they are published online, and connects the same identifier to all online and print versions of the publication. SPIE uses a seven-digit CID article numbering system structured as follows:

- The first five digits correspond to the SPIE volume number.

- The last two digits indicate publication order within the volume using a Base 36 numbering system employing both numerals and letters. These two-number sets start with $00,01,02,03$, 04, 05, 06, 07, 08, 09, OA, OB ... OZ, followed by 10-1Z, 20-2Z, etc. The CID Number appears on each page of the manuscript. 


\title{
Contents
}

\author{
vii Authors \\ ix Conference Committee \\ xi 2018 Medical Imaging Award Recipients
}

SESSION 1 KEYNOTE AND IMAGE PERCEPTION I

1057703 Do radiographers base the diagnostic acceptability of a radiograph on anatomical structures? [10577-2]

1057704 A cognitive approach to determine the benefits of pairing radiologists in mammogram reading [10577-3]

\section{SESSION 2 IMAGE PERCEPTION II}

1057705 Restored low-dose digital breast tomosynthesis: a perception study [10577-4]

1057706 A database for assessment of effect of lossy compression on digital mammograms [10577-5]

1057707 Analysis of visual search behaviour from experienced radiologists interpreting digital breast tomosynthesis (DBT) images: a pilot study [10577-6]

1057708 A deep (learning) dive into visual search behaviour of breast radiologists [10577-7]

1057709 Comparing salience detection algorithms in mammograms [10577-8]

10577 OA Satisfaction at last: evidence for the 'satisfaction' account for multiple-target search errors [10577-9]

\section{SESSION 3 OBSERVER PERFORMANCE EVALUATION I}

10577 OB Model and human observer reproducibility for detecting microcalcifications in digital breast tomosynthesis images [10577-10]

10577 OC Evaluation of search strategies for microcalcifications and masses in 3D images [10577-11]

10577 OD Comparison of microcalcification detectability in FFDM and DBT using a virtual clinical trial [10577-12] 
10577 OE Analyzing ROC curves using the effective set-size model [10577-13]

10577 OF Efficiency gain of paired split-plot designs in MRMC ROC studies [10577-14]

\section{SESSION 4 TECHNOLOGY ASSESSMENT}

10577 OG Interaction of anatomic and quantum noise in DBT power spectrum [10577-15]

$10577 \mathrm{OH} \quad$ Comparison of synthetic 2D images with planar and tomosynthesis imaging of the breast using a virtual clinical trial [10577-16]

10577 Ol Assessment of DBT acquisition parameters for 2D and 3D search tasks [10577-17]

10577 OJ Quantifying predictive capability of electronic health records for the most harmful breast cancer [10577-18]

10577 OK Test data reuse for evaluation of adaptive machine learning algorithms: over-fitting to a fixed 'test' dataset and a potential solution [10577-19]

$10577 \mathrm{OL}$ Towards the use of computationally inserted lesions for mammographic CAD assessment [10577-20]

\section{SESSION 5 MODEL OBSERVERS I}

10577 OM Correlation between model observers in uniform background and human observers in patient liver background for a low-contrast detection task in CT [10577-21]

10577 ON Lesion detection performance of cone beam CT images with anatomical background noise: single-slice vs. multi-slice human and model observer study [10577-22]

1057700 A practical method to evaluate personalized injected patient dose for cardiac perfusion SPECT imaging: the polar map as a numerical observer [10577-23]

10577 OP Parameter selection with the Hotelling observer in linear iterative image reconstruction for breast tomosynthesis [10577-24]

$105770 Q \quad$ A deep learning model observer for use in alterative forced choice virtual clinical trials [10577-25]

\section{SESSION 6 MODEL OBSERVERS II}

10577 OR Towards a surround-aware numerical observer [10577-26]

10577 OS Evaluation of a machine learning based model observer for x-ray CT [10577-27]

10577 OT Observer templates in 2D and 3D localization tasks [10577-28] 
10577 OU Reducing the number of reconstructions needed for estimating channelized observer performance [10577-29]

10577 OV Resampling techniques comparison for CHO's performance and uncertainty estimation [10577-30]

SESSION 7 OBSERVER PERFORMANCE EVALUATION II AND TRIBUTE TO ART BURGESS

10577 OW Reader performance in visual assessment of breast density using visual analogue scales: Are some readers more predictive of breast cancer? [10577-31]

10577 OX Interactions of lesion detectability and size across single-slice DBT and 3D DBT [10577-32]

10577 OY Lesion classification with a visual-search model observer [10577-33]

$105770 Z$ A citizen science approach to optimising computer aided detection (CAD) in mammography [10577-34]

1057710 Can a limited double reading/second opinion of initially recalled breast ultrasound screening examinations improve radiologists' performances? [10577-35]

POSTER SESSION

1057712 Study of CT image texture using deep learning techniques [10577-36]

1057713 Assessment of computerized algorithms by comparing with human observers in binary classification tasks: a simulation study [10577-37]

1057714 Development of a validation instrument in myocardial perfusion imaging: results of first flow experiments [10577-38]

1057716 Ischemic stroke enhancement in computed tomography scans using a computational approach [10577-40]

1057717 Projection space model observers based on marginal linear discriminants [10577-41]

1057718 Characteristics of the group of radiologists that benefits the most using Breast Screen Reader Assessment Strategy (BREAST) [10577-42]

1057719 Learning the ideal observer for SKE detection tasks by use of convolutional neural networks (Cum Laude Poster Award) [10577-43]

10577 1A Blind CT image quality assessment via deep learning strategy: initial study [10577-44]

10577 1B Can a totally different approach to soft tissue computer aided detection (CADe) result in affecting radiologists' decisions? [10577-45]

10577 1C Feasibility study of deep convolutional generative adversarial networks to generate mammography images [10577-46] 
10577 ID Simulating magnetic resonance images based on a model of tumor growth incorporating microenvironment [10577-47]

10577 IE Breast elastography: identification of benign and malignant cancer based on absolute elastic modulus measurement using vibro-elastography [10577-48]

$10577 \mathrm{iF} \quad$ Local-search based prediction of medical image registration error [10577-49] 


\section{Authors}

Numbers in the index correspond to the last two digits of the seven-digit citation identifier (CID) article numbering system used in Proceedings of SPIE. The first five digits reflect the volume number. Base 36 numbering is employed for the last two digits and indicates the order of articles within the volume. Numbers start with 00, 01, 02, 03, 04, 05, 06, 07, 08, 09, OA, OB...0Z, followed by 10-12, 20-2Z, etc.

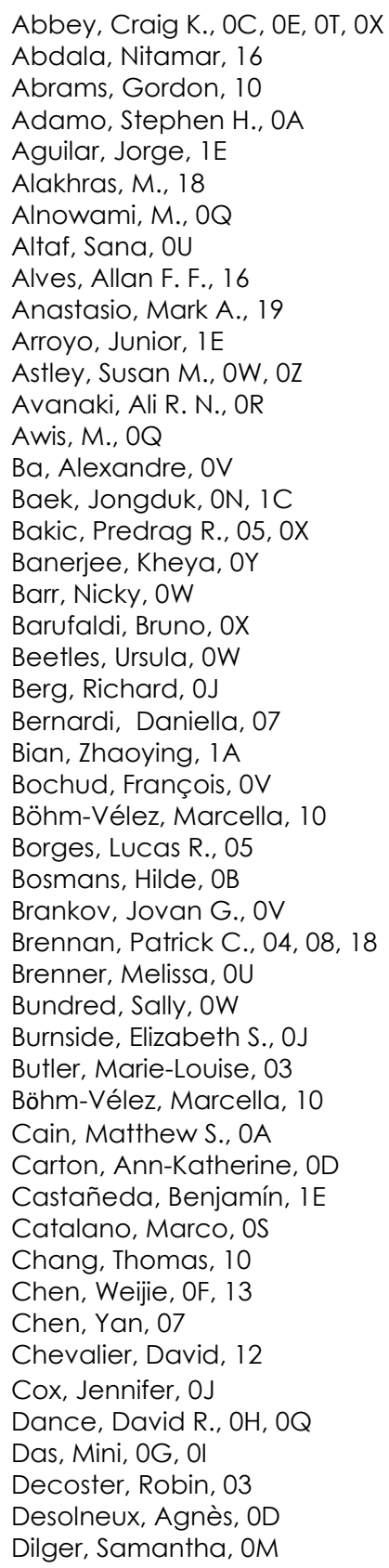

Dong, Leng, 07

Dutta, Sandeep, 12

Eckstein, Miguel P., OC, OT, OX

Elangovan, Premkumar, $\mathrm{OH}, \mathrm{OQ}$

Espig, Kathryn S., OR

Evans, D. Gareth, OW

Fan, Jiahua, 12

Fan, Jun, OJ

Foden, Philip, OW

Fredette, Nathaniel R., OG

Freitas, Carlos C. M., 16

Gadde, Soujanya, OW

Gale, Alastair, 07

Gallas, Brandon D., OF

Gandomkar, Ziba, 04

Ganesan, A., 18

Ganott, Marie A., 10

Ghanian, Zahra, OL

Gifford, Howard C., OI, OY, 17

Gizienski, Terri-Ann, 10

Gong, Hao, OM

Gong, Qi, OF

Gossmann, Alexej, OK

Greuter, Marcel J. W., 14

Guerrero, Jorge, 1E

Gur, David, 10, 1B

Hakim, Christiane, 10

Halling-Brown, M., $0 Q$

Han, Minah, ON

Harkness, Elaine F., OW, $0 Z$

Harnist, Kimberly, 10

Hawkins-Daarud, Andrea, ID

$\mathrm{He}, \mathrm{Ji}, \mathrm{IA}$

He, Xin, OE

Howell, Anthony, OW

Huang, Zhipeng, 13

Hulleman, Johan, $\mathrm{OZ}$

Ionescu, Georgia V., $0 Z$

Jackson, Pamela R., ID

Jain, Anil, OW

Jang, Hanjoo, ON

Jennane, Rachid, 16

Johnson, Karen L., 00

Kamphuis, Marije E., 14

Karbaschi, Zohreh, 17

Kaur, Sukhmanjit, $\mathrm{OH}$

Kavuri, Amar, OG

Kelly, Amy E., 10

Kim, Gihun, 1C 
Kimpe, Tom R. L., OR

Kinahan, Paul E., 1D

King, Michael A., 00

Kopp, Felix K., OS

Lago, Miguel A., OC, OT, OX

Landino, Kristina, 09

Lavarello, Roberto, $1 \mathrm{E}$

Lee, W., 18

Leng, Shuai, OM

Li, Sui, 1 A

Li, Zhijin, OD

Liao, Yuting, 1A

Lim, Yit Y., OW

Lobo, Julio, 1E

Loew, Murray, 09

Lu, Amy, 10

Ma, Jianhua, $1 \mathrm{~A}$

Mackenzie, Alistair, $\mathrm{OH}$

Maidment, Andrew D. A., 05, OX

Mall, Suneeta, 08

Marshall, Nicholas, OB

Massanes, Francesc, OV

Maxwell, Anthony, OW

McCollough, Cynthia H., OM

Mello-Thoms, Claudia, 04, 08, 18

Miedema, Hope, OU

Milioni de Carvalho, Pablo, OD

Mills, G., OQ

Miranda, José R. A., 16

Mitroff, Stephen R., OA

Montenegro, Pilar, $1 \mathrm{E}$

Muller, Serge, OD

Noël, Peter B., OS

Page, David, OJ

Pan, Xiaochuan, OP

Partridge, Savannah C., ID

Patel, M., OQ

Pavan, Ana L. M., 16

Peissig, Peggy, 0J

Pelgrim, Gert Jan, 14

Petrick, Nicholas, 06, 0L, 13

Petrov, Dimitar, OB

Pezeshk, Aria, 06, OK, OL

Pfeiffer, Daniela, OS

Pina, Diana R., 16

Pineda, Angel R., OU

Pinto, Joseph A., 1E

Pretorius, P. Hendrik, 00

Rayner, Millicent, OW

Reiser, Ingrid, OP

Ren, Liqiang, OM

Rose, Sean D., OP

Roth, Jacob, OP

Rummeny, Ernst J., OS

Saavedra, Ana Cecilia, 1E

Sahiner, Berkman, 06, OK, OL, 13

Salcudean, Tim, $1 \mathrm{E}$

Samuelson, Frank W., OE

Saygili, Görkem, IF

Shim, Hyunjung, 1C
Sidky, Emil Y., OP

Slart, Riemer H. J. A., 14

Slump, Cornelis H., 14

Sobolewski, Robin, 10

Sumkin, Jules, 10

Swanson, Kristin R., 1D

Tafti, Ahmad Pahlavan, OJ

Tang, Qiang, 07

Tapia, K., 18

Toomey, Rachel, 03

Tyma, Cathy S., 10

Vieira, Marcelo A. C., 05

Wang, Jiheng, 06

Wang, Yongbo, 1A

Weinstein, Susan P., OX

Wells, K., OQ

Wilson, Mary, OW

Wu, Yirong, OJ

Xthona, Albert, OR

Yang, Yang, 13

Yin, Jie, OJ

Young, Kenneth $\mathrm{C}$., $\mathrm{OB}, \mathrm{OH}, \mathrm{OQ}$

Yu, Lifeng, OM

Yuan, Ming, OJ

Zeng, Dong, $1 \mathrm{~A}$

Zhou, Wei, OM

Zhou, Weimin, 19

Zimmerman, Cole, OP

Zuley, Margarita, 10 


\section{Conference Committee}

Symposium Chairs

Leonard Berliner, Weill Cornell Medical College (United States) and New York Presbyterian - Brooklyn Methodist Hospital (United States)

Ronald M. Summers, National Institutes of Health (United States)

Conference Chairs

Robert M. Nishikawa, University of Pittsburgh (United States)

Frank W. Samuelson, U.S. Food and Drug Administration

(United States)

Conference Program Committee

Craig K. Abbey, University of California, Santa Barbara (United States) Jongduk Baek, Yonsei University (Korea, Republic of)

François O. Bochud, Centre Hospitalier Universitaire Vaudois

(Switzerland)

Jovan G. Brankov, Illinois Institute of Technology (United States)

Yan Chen, Loughborough University (United Kingdom)

Brandon D. Gallas, U.S. Food and Drug Administration (United States)

Howard C. Gifford, University of Houston (United States)

Stephen L. Hillis, The University of lowa (United States)

Elizabeth A. Krupinski, Emory University School of Medicine (United States)

Matthew A. Kupinski, College of Optical Sciences, The University of Arizona (United States)

Maciej A. Mazurowski, Duke University (United States)

Mark F. McEntee, The University of Sydney (Australia)

Claudia R. Mello-Thoms, The University of Sydney (Australia) and University of Pittsburgh (United States)

Ljiljana Platiša, Universiteit Gent (Belgium)

Ingrid S. Reiser, The University of Chicago (United States)

Sian Taylor-Phillips, The University of Warwick (United Kingdom)

Pontus A. Timberg, Scanias University Hospital (Sweden)

David L. Wilson, Case Western Reserve University (United States) 


\section{Session Chairs}

1 Keynote and Image Perception I

Robert M. Nishikawa, University of Pittsburgh (United States)

Frank W. Samuelson, U.S. Food and Drug Administration

(United States)

2 Image Perception II

Claudia R. Mello-Thoms, The University of Sydney (Australia) and University of Pittsburgh (United States)

Elizabeth A. Krupinski, Emory University School of Medicine (United States)

3 Observer Performance Evaluation I

Stephen L. Hillis, The University of lowa (United States)

Jongduk Baek, Yonsei University (Korea, Republic of)

4 Technology Assessment

Craig K. Abbey, University of California, Santa Barbara (United States)

David L. Wilson, Case Western Reserve University (United States)

5 Model Observers I

Matthew A. Kupinski, College of Optical Sciences, The University of Arizona (United States)

Ljiljana Platiša, Universiteit Gent (Belgium)

6 Model Observers II

Howard C. Gifford, University of Houston (United States)

7 Observer Performance Evaluation II and Tribute to Art Burgess

Elizabeth A. Krupinski, Emory University School of Medicine (United States)

Yan Chen, Loughborough University (United Kingdom) 


\section{Medical Imaging Award Recipients}

\section{Robert F. Wagner Best Student Paper Award}

Robert F. Wagner was an active scientist in the SPIE Medical Imaging meeting, starting with the first meeting in 1972 and continuing throughout his career. He ensured that the $\mathrm{BRH}$, and subsequently the $\mathrm{CDRH}$, was a sponsor for the early and subsequent Medical Imaging meetings, helping to launch and ensure the historical success of the meeting. The Robert $F$. Wagner All-Conference Best Student Paper Award (established 2014) is acknowledgment of his many important contributions to the Medical Imaging meeting and his many important advances to the field of medical imaging.

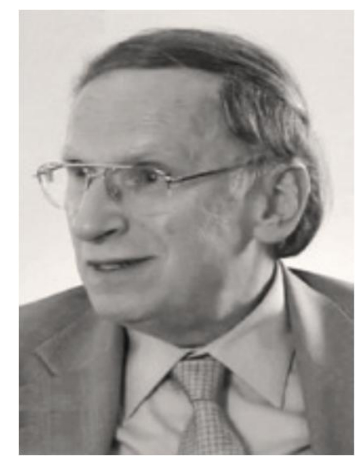

This award is co-sponsored by:

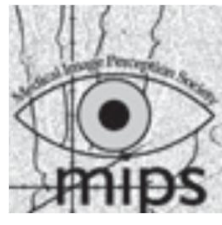

The Medical Image Perception Society

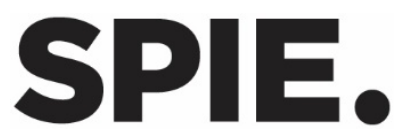

\section{Recipients:}

First Place: Dynamic beam filtering for miscentered patients (10573-29)

Andrew Mao, William Shyr, Grace J. Gang, J. Webster Stayman, Johns Hopkins Univ. (United States)

Second Place: Tumor margin classification of head and neck cancer using hyperspectral imaging and convolutional neural networks (10576-4)

Martin Halicek, Georgia Institute of Technology (United States) and Augusta Univ. (United States); James V. Little, Xu Wang, Emory Univ. School of Medicine (United States); Mihir Patel, Emory Univ. School of Medicine (United States) and The Winship Cancer Institute of Emory Univ. (United States); Christopher C. Griffith, Emory Univ. School of Medicine (United States); Amy Y. Chen, Emory Univ. School of Medicine (United States) and The Winship Cancer Institute of Emory Univ. (United States); Baowei Fei, Georgia Institute of Technology \& Emory Univ. (United States) and The Winship Cancer Institute of Emory Univ. (United States) 
Proc. of SPIE Vol. 10577 1057701-12 Downloaded From: https://www.spiedigitallibrary.org/conference-proceedings-of-spie on 26 Apr 2023
Terms of Use: https://www.spiedigitallibrary.org/terms-of-use 